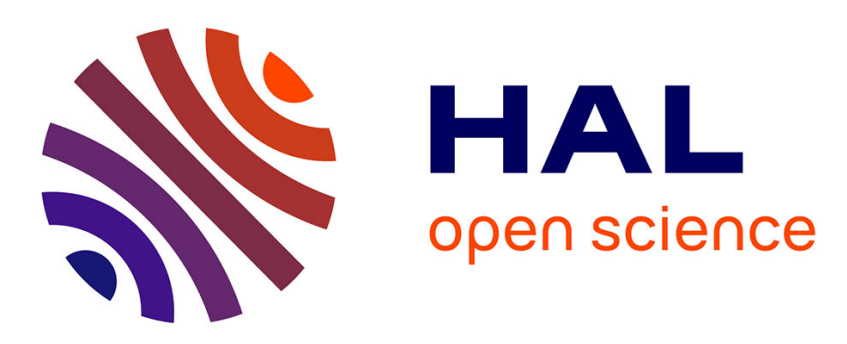

\title{
Probing the Brønsted Acidity of the External Surface of Faujasite-Type Zeolites
}

Louwanda Lakiss, Aurélie Vicente, Jean-Pierre Gilson, Valentin Valtchev, Svetlana Mintova, Alexandre Vimont, Robert Bedard, Suheil Abdo, Jeffery Bricker

\section{To cite this version:}

Louwanda Lakiss, Aurélie Vicente, Jean-Pierre Gilson, Valentin Valtchev, Svetlana Mintova, et al.. Probing the Brønsted Acidity of the External Surface of Faujasite-Type Zeolites. ChemPhysChem, 2020, 21 (16), pp.1873-1881. 10.1002/cphc.202000062 . hal-03027937

\section{HAL Id: hal-03027937}

\section{https://hal-normandie-univ.archives-ouvertes.fr/hal-03027937}

Submitted on 27 Nov 2020

HAL is a multi-disciplinary open access archive for the deposit and dissemination of scientific research documents, whether they are published or not. The documents may come from teaching and research institutions in France or abroad, or from public or private research centers.
L'archive ouverte pluridisciplinaire HAL, est destinée au dépôt et à la diffusion de documents scientifiques de niveau recherche, publiés ou non, émanant des établissements d'enseignement et de recherche français ou étrangers, des laboratoires publics ou privés. 


\title{
Probing the Brønsted acidity of the external surface of Faujasite type zeolites
}

\author{
Louwanda Lakiss $^{\dagger}$, Aurélie Vicente ${ }^{\dagger}$, Jean-Pierre Gilson ${ }^{\dagger *}$, Valentin Valtchev ${ }^{\dagger}$, Svetlana \\ Mintova $^{\dagger}$, Alexandre Vimont ${ }^{\dagger}$, Robert Bedard ${ }^{\ddagger}$, Suheil Abdo ${ }^{\ddagger}$, Jeffery Bricker ${ }^{\ddagger}$ \\ $\dagger$ Normandie Univ, ENSICAEN, UNICAEN, CNRS, Laboratoire Catalyse et Spectrochimie, 14000 Caen, \\ France \\ † UOP LLC, 25 East Algonquin Road, Des Plaines, IL 60016, USA
}

ORCID Numbers of authors:

Louwanda Lakiss : https://orcid.org/0000-0002-6693-3773
Jean-Pierre Gilson : https://orcid.org/0000-0002-3543-8163
Valentin Valtchev : https://orcid.org/0000-0002-2341-6397
Svetlana Mintova : https://orcid.org/0000-0002-0738-5244
Alexandre Vimont : https://orcid.org/0000-0001-9799-6024

KEYWORDS: Faujasite, Triphenylphosphine oxide, 2,4,6 Tri-tert-butylpyridine, phosphorous NMR spectroscopy, Infrared spectroscopy.

\begin{abstract}
We outline two methodologies to selectively characterize the Brønsted acidity of the external surface of FAU-type zeolites by IR and NMR spectroscopy of adsorbed basic probe molecules. The challenge and goal are to develop reliable and quantitative IR and NMR methodologies to investigate the accessibility of acidic sites in the large pore FAU-type zeolite Y and its mesoporous derivatives often referred to as ultrastable Y (USY). The accessibility of their Brønsted acid sites to probe molecules (n-alkylamines, n-alkylpyridines, n-alkylphosphine- and phenylphosphineoxides) of different molecular sizes is quantitatively monitored either by IR or ${ }^{31} \mathrm{P}$ NMR spectroscopy. It is now possible, for the first time to quantitatively discriminate between the Brønsted acidity located in the microporosity and on the external surface of large pore zeolites.
\end{abstract}

\section{INTRODUCTION}

Zeolite catalysts are currently widely used in oil refining and petrochemical processes and their applications are set to grow further in these classical and other more emerging applications. ( ${ }^{1,2,3,4,5,6}$ ) Their high surface areas and micropore volumes, tunable acidity, active sites located in confined spaces, unique shape selectivity and many other easily adjustable properties make them often the catalysts or adsorbents of choice for various industrial processes. $\left({ }^{2,3,4}\right)$ These desired properties come at a price, internal mass transport limitations lowering their potential catalytic performances, $\left({ }^{7}\right)$ although such limitations can also be effective tools to engineer unique selectivities. $\left({ }^{8}\right)$ The interplay between internal mass transport and chemical kinetics in zeolite catalysis is often described using the Thiele modulus $(\Phi)$ approach. $\left({ }^{7}\right)$ However, as it explicitly does not take into account the external surface of zeolites, the approach might become less relevant when effective particle size decreases during top-down (biased or unbiased demetallation generating intracrystalline mesoporosity) or bottom-up (direct synthesis of nanosized zeolite crystals generating intercrystalline mesoporosity) hierarchization procedures. $\left(^{9}\right)$ When the external surface of zeolites, where confinement differs from inside the microporosity, is explicitly taken into account in computing the Thiele modulus, it was shown recently that its effect on catalyst effectiveness $(\eta)$ decreases. $\left({ }^{10}\right)$ Although impressive advances in the last few years enabled a better description of the micro- and meso-porous volumes and surfaces of zeolites by physisorption of 
Nitrogen, Argon and Krypton at low temperatures, these methods do not provide any information on the surface acidity. $\left({ }^{11}\right)$ In principle, the external surface acidity should increase with added mesoporosity and decreasing crystal size, but zoning can occur due either to synthesis conditions or biased post-synthesis treatments leading to unpredictable acid site concentrations. $\left({ }^{12,13,14}\right)$

Moreover, zeolite powders are always shaped in the presence of a binder when used in industrial processes. This is required to optimize many, often conflicting, specifications such as mechanical and thermal resilience, pressure drop and hydrodynamics management in the reactor... $\left({ }^{15}\right)$ During such an operation, a zeolite powder is successively mixed and kneaded with an inorganic binder precursor (e.g. pseudoboehmite) and other additives (peptizing agents, porogens, filler...), shaped (yielding so called green extrudates), dried and then calcined at temperatures above $800 \mathrm{~K}$. Under such conditions, chemical interactions between inorganic binders and zeolite surfaces are likely to occur. As reported elsewhere, zeolite surface properties and more specifically their external acidity are affected during these operations altering their catalytic performances. $\left({ }^{16}\right)$ Zeolite acidity is multifarious (e.g. nature, number, strength, location and distribution across the crystallites, confinement, accessibility...). The potential differences in accessibility and confinement between acid sites located anywhere in the microporosity (hereinafter referred to as internal acidity) and on the external surface of crystallites or any mesoporosity (hereinafter referred to as external acidity) are particularly important. $\left({ }^{17,18,19}\right)$

Numerous techniques are currently used to characterize the acidic properties of zeolites such as ammonia and alkylamines $\left({ }^{20}\right)$ temperature-programmed desorption (TPD), $\left({ }^{21,22}\right)$ infrared spectroscopy (IR), $\left({ }^{23,24,25,26,27,28,29,30,31}\right)$ and nuclear magnetic resonance $\left({ }^{1} \mathrm{H}\right.$ and ${ }^{31} \mathrm{P}$ NMR) spectroscopy of adsorbed basic probe molecules. $\left({ }^{32,33}\right)$

The number of acid sites determined by adsorption of probe molecules is often lower than expected from their framework (Si/Al) composition, $\left({ }^{34}\right)$ due to their accessibility to probe molecules. This led to the definition of an accessibility index (ACI), the ratio between the maximum number of acid sites determined by a given probe molecule and the number expected from their framework composition. $\left({ }^{35}\right)$ An alternative approach to estimate the acid site density is the consecutive adsorption of probe molecules of decreasing size to better discriminate acid sites distributed in various environments. $\left({ }^{36,37}\right)$ For instance, the accessibility of the acid sites of mordenite (located either in large channels or more confined side-pockets) and mesoporous derivatives was determined by the consecutive adsorption of substituted alkylpyridines (2,4,6-triethylpyridine 2,4,6-trimethylpyridine and pyridine) and carbon monoxide. $\left({ }^{37}\right)$ Recently, Freitas et al. also used IR spectroscopy of alkylpyridines to map the accessibility of acid sites in MFI and BEA zeolites. They highlight that 2,6-dimethylpyridine accesses $50 \%$ of the acidic sites in ZSM-5 while 2,4,6 trimethylpyridine and 2,6 di-tertbutylpyridine reach only 8 and $5 \%$ of the acidic sites, respectively. $\left({ }^{38}\right)$ Nitriles probes with different sizes were also used to differentiate external and internal acid sites present in ZSM-5 zeolites. $\left({ }^{39}\right)$ Other probe molecules were also used to determine acid sites accessibility in zeolite such as FER, BEA, ZSM-5 and MCM$(22.31,40,41,42,43)$ Another, yet unexplored, option could be the deuteration of acid sites by molecules of increasing sizes, initially developed to map the accessibility of silanols in amorphous silicas. $\left({ }^{44}\right){ }^{31} \mathrm{P}$ NMR spectroscopy, with its large window of chemical shifts and easy quantification (natural abundance and spin $1 / 2$ ) is becoming popular to measure zeolite acidity with phosporous probes: trimethylphosphine oxide is a good example as it provides information on the number, type (Lewis and Brønsted) and strength of zeolitic acid sites..$^{33,38,45,46,47,48,49,50,51}$ ) Earlier analyses, performed with trimethylphosphine (TMP) $\left({ }^{52,53}\right.$ ) are now replaced by the more stable and less hazardous alkylphosphine oxides. Trimethylphosphine oxide (TMPO), for instance, was used to probe acidity in amorphous silica-aluminas, aluminas, and zeolites. ${ }^{46}$ ) Mafra et al. used a combination of alkylphosphine oxides of different sizes (trimethylphosphine [TMPO, kinetic diameter: $0.55 \mathrm{~nm}$ ]) and tributylphosphine oxide [TBPO, kinetic diameter: $0.82 \mathrm{~nm}$ ]), to successfully discriminate the internal from the external acidity of ZSM-5 zeolites. ${ }^{50}$ ) Chemical reactions should be the ultimate way to assess the acidity and catalytic activity of the external surface of zeolites $\left({ }^{54,55,56}\right)$ but it is often challenging to prove that either reactants, intermediates or some products do not penetrate their microporosity at reaction temperatures.

As far as industrial applications are concerned, it is well recognized that Brønsted acid sites located on the external surface (e.g. MWW) or at the pore-mouths (e.g. MTT, TON...) of some zeolites, are the active sites for some important reactions as cumene synthesis and the selective hydroconversion of long-chain n-paraffins to their monobranched isomers. ${ }^{57}$ ) On the other hand, when p-xylene is produced industrially on MFI-based catalysts, either by mixed xylene isomerization, toluene disproportionation or alkylation, their external surface active sites are selectively deactivated by reaction with, for instance, organo-nitrogen or -phosphorous compounds. $\left({ }^{58,59}\right)$

So far, all methodologies describing the acidity of the external surface of zeolites fail when applied to the FAU structure, in its purely microporous form (Y) and even more on its mesoporous derivatives (USY). A ${ }^{31} \mathrm{P} N M R$ study of rare earth zeolite Y using TMPO and TBPO reported that TBPO does not access zeolite Y microporosity and estimated its concentration of external acidic sites at $120 \mu \mathrm{mol} / \mathrm{g}$, i.e. about $3 \%$ of the total acid sites. $\left({ }^{45}\right)$ However, this zeolite, with a $\mathrm{Si} / \mathrm{Al}$ ratio of 3.7, was certainly dealuminated, i.e. already possessed some mesoporosity as well as extraframework species potentially restricting the accessibility of some probe molecules; this could raise doubts on the accessibility of TBPO to the native microporosity of zeolite Y.

The FAU type structure is by far the most widely used zeolite in industrial processes: $i$ ) the so-called Y or USY $(\mathrm{Si} / \mathrm{Al} \geq 2.5)$ mostly as a catalyst (Hydrocracking, Fluid Catalytic Cracking [FCC], Aromatics alkylation...) $\left.\left({ }^{6}\right), i i\right)$ the so-called $\mathrm{X}(\mathrm{Si} / \mathrm{Al} \sim 1.0)$ mostly as an adsorbent (aromatics separations...). Its crystalline structure, made of sodalite 
cages (cuboctahedral units) linked by hexagonal prisms (double six rings), generates a microporosity in supercages of about $1.2 \mathrm{~nm}$ in diameter accessible to relatively bulky molecules; $\left({ }^{60}\right)$ the sodalite cages remain inaccessible to most probe molecules unless opened by chemical treatment. $\left({ }^{61}\right)$ As-synthesized Y zeolite is usually in its sodium form and acidity generated by ammonium exchange(s) followed by calcination(s). During calcination, partial dealumination and/or amorphisation can occur. Zeolite $\mathrm{Y}$ is often dealuminated by steaming at high temperatures and/or acid leaching to prepare a more stable form, the so-called ultrastable Y (USY). During this process, some aluminum is expelled from the framework and mesoporosity added to its native microporosity creating a hierarchical material, provided microand meso-porosity are sufficiently connected. The acidic (number, strength, location, accessibility, distribution...) and textural properties of the zeolite are therefore modified during this process. In particular, the confinement in a significant proportion of acid sites will change as the microporosity will decrease and intracrystalline mesoporosity will be added, i.e. the internal/external acidity ratio will increase. This ratio is also substantially increased, with the formation of intercrystalline mesoporosity, when small crystals $(<100 \mathrm{~nm})$ of zeolites are synthesized, the so-called nanozeolites. $\left({ }^{62,63}\right)$

In IR spectroscopy, the preferred methodology to quantify acid properties, the stepwise addition of calibrated doses of a basic probe molecule is the norm. It is however a challenge to find suitable probe molecules (liquid with a vapor pressure of about 0.1 torr) not entering the zeolite Y microporosity due to the dimension $(0.74 \mathrm{~nm})$ of the windows (12 MR, twelve $T$ atoms delineating a ring) leading to its supercages. Two criteria need consideration when selecting such suitable probe molecules: their kinetic diameter and the adsorption temperature. A trusted rule of thumb states that molecules with a kinetic diameter $20 \%$ larger than a zeolite pore will enter the porosity as temperature increases. $\left({ }^{55,64}\right)$ Accordingly, a molecule probing the external surface of FAU type structures should have a kinetic diameter superior to $0.9 \mathrm{~nm}$. $\left({ }^{55}\right) 2,4$ dimethylquinoline $(2,4 \mathrm{DMQ})$ is a potential candidate and was already used to probe the external acidity of some zeolites. $\left({ }^{31}\right)$ As it accesses, at $423 \mathrm{~K}$, the microporosity of BEA and FAU structures, lowering its adsorption to room temperature might prevent or significantly delay its diffusion in the FAU microporosity.

We screened other basic molecules using these criteria to monitor the FAU external surface acidity by IR $(2,4$ dimethylquinoline [DMQ, $0.91 \mathrm{~nm}$ ], 2,6 di-tert-butylpyridine [DTBPy, $0.8 \mathrm{~nm}$ ], 2,4,6 tri-tert-butylpyridine [TTBPy, $1.1 \mathrm{~nm}]$ ) or ${ }^{31} \mathrm{P}$ NMR (triphenylphosphine oxide [TPhPO, $\left.1.1 \mathrm{~nm}\right]$ ) spectroscopies. In addition, as trimethylamine (TMA) was already used to measure the strength of acid sites in zeolite $\mathrm{Y}$, we selected two bulkier alkylamines (tributylamine [TBA, $1.1 \mathrm{~nm}$ ] and trihexylamine [THA, $1.3 \mathrm{~nm}$ ]). 30 The more classical probes, Pyridine (IR) and TMPO (NMR) were used to quantify the maximum accessible acidity of zeolite Y and its USY derivatives. These probe molecules along with some selected properties are described in Table S.1.

\section{EXPRIMENTAL SECTION}

Three commercial zeolites were investigated: $i$ ) Y: LZY-64 supplied by UOP, ii) USY's: CBV720 and CBV760 purchased from Zeolyst. Some typical physicochemical properties are summarized in Table 1. USY's are typical of steamed (CBV720) and steamed/acid leached (CBV760) Y zeolites. Their Si/Al ratios range from 2.3 to 28 and they differ significantly by their acidic and textural properties. As expected, USY's display higher mesoporosity than their Y parent.

Probe molecules with different sizes and basicities, namely Pyridine (Py, $99.8 \%$ ), 2,6 Di-tert-butylpyridine (DTBPy, >97 \%), 2,4 Dimethyl quinoline (DMQ, 95\%), Tributylamine (TBA, $99.5 \%$ ), Trihexylamine (THA, $96 \%$ ) and 2,4,6 Tri-tert-butylpyridine (TTBPy, 99\%) were purchased from Sigma-Aldrich and used without further purification.

With the exception of Py, DTBPy and TTBPy, the molar absorption coefficients of bands characteristic of the protonated probe molecules were not determined. Instead, the Brønsted acid site concentrations were measured by integrating the $v(\mathrm{OH})$ bands at $3630 \mathrm{~cm}^{-1}\left(\mathrm{OH}_{\mathrm{HF}}\right.$, located in the supercages $)$ and $3550 \mathrm{~cm}^{-1}\left(\mathrm{OH}_{\mathrm{LF}}\right.$, located in the sodalite cages) before and after adsorption of the probe molecules. Their respective molar absorption coefficients $(\varepsilon$ $\mathrm{OH}_{\mathrm{HF}}=6.76 \mathrm{~cm} \cdot \mathrm{mol}^{-1}$ and $\varepsilon \mathrm{OH}_{\mathrm{LF}}=5.39 \mathrm{~cm} \cdot \mathrm{mol}^{-1}$ ) were determined, very accurately, earlier in a homemade setup (AGIR), by monitoring simultaneously weight gains/losses on a thermobalance (AG) fitted with a cell recording the IR spectra of the adsorbed probes. $\left({ }^{24}\right)$

IR spectra were recorded with a Nicolet Magna 550-FT-IR spectrometer at $4 \mathrm{~cm}^{-1}$ optical resolution. Prior to the measurements, the zeolites were pressed into self-supporting discs (diameter: $1.6 \mathrm{~cm}, 18 \mathrm{mg}$ ) and pretreated in the IR cell attached to a vacuum line $\left(10^{-6}\right.$ Torr), first at $393 \mathrm{~K}$ for 2 hours followed by a ramp to $723 \mathrm{~K}(3 \mathrm{~K} / \mathrm{min})$ held for 2 h. The adsorption temperature of Pyridine ( 1 torr at equilibrium) and 2,6 Di-tert-butylpyridine ( 0.2 torr at equilibrium) were $373 \mathrm{~K}$ and $423 \mathrm{~K}$, respectively. DMQ, TBA, THA, and TTBPy (0.1-0.2 torr) adsorptions were performed at 298 $\mathrm{K}$. After equilibration with the probe molecules, the cell was outgassed to remove the physisorbed species. All spectra were normalized to the same mass (20 mg wafers). The amounts of pyridine adsorbed on the Brønsted and Lewis acid sites were determined by integrating the area of the characteristic bands corresponding to pyridinium ions $\left(1545 \mathrm{~cm}^{-1}\right)$ and coordinated pyridine $\left(1454 \mathrm{~cm}^{-1}\right)$ using their respective molar absorption coefficients $(\varepsilon 1545=1.35$ and $\varepsilon 1454=$ $\left.1.8 \mathrm{~cm} \cdot \mathrm{mol}^{-1}\right) \cdot\left({ }^{24}\right)$ As TTBPy is solid at room temperature (melting point: $343 \mathrm{~K}$ and boiling point: $393 \mathrm{~K}$ ), an alternative procedure was followed for its adsorption. A self-supported wafer of solid TTBPy was first prepared and 
transferred to a small calibrated volume enclosed between 2 valves in the IR cell (Figure S1). After evacuation under vacuum, this volume is isolated during the activation of the zeolite; the valve is then opened to start the TTBPy adsorption.

A homemade cell was used to perform the NMR experiments (Figure S.2). As outlined above, two different molecules were selected: $i$ ) Trimethylphosphine oxide (TMPO) to access both the internal and external acidity, ii) Triphenylphosphine oxide (TPhPO) to access only the external acidity. The samples were first dehydrated under vacuum $\left(10^{-6}\right.$ Torr) at $723 \mathrm{~K}$ (reached at $\left.3 \mathrm{~K} / \mathrm{min}\right)$ for $2 \mathrm{~h}$, a solution of TMPO $(4 \mathrm{mmol} / \mathrm{l})$ or TPhPO $(0.4 \mathrm{mmol} / \mathrm{l}) \mathrm{in}$ $\mathrm{CH}_{2} \mathrm{Cl}_{2}$ then poured on the zeolite in a glove box filled with argon and equilibrated for 15 min under ultra-sonication. The cell was then connected to a vacuum line (Pressure $=10^{-4}$ torr) and evacuated at $298 \mathrm{~K}$ for 2 hours, the product recovered transferred to an argon filled glove box and loaded in an NMR rotor. The NMR spectra were recorded on a Bruker Avance 500 and the samples spun at the magic angle at a frequency of $12 \mathrm{kHz}$ with a single pulse width of 8.5 $\mu \mathrm{s}$ and a recycle delay of $10 \mathrm{~s}$. The ${ }^{31} \mathrm{P}$ chemical shifts were measured relative to an aqueous $\mathrm{H}_{3} \mathrm{PO}_{4}(85 \%)$.

Table 1. Physico-chemical properties of the parent zeolite powders

\begin{tabular}{l|lll} 
Zeolite & LZY-64 & CBV720 & CBV760 \\
\hline${\text { Unit cell parameter }(\AA)^{\mathrm{a}}}^{\mathrm{a}}$ & 24.7 & 24.3 & 24.2 \\
$\mathrm{Si} / \mathrm{Al}_{\text {Framework }} \mathrm{b}^{\mathrm{b}}$ & 2.3 & 16 & 28 \\
$\mathrm{~V}_{\text {Micro }}\left(\mathrm{cm}^{3} / \mathrm{g}\right)^{\mathrm{c}}$ & 0.34 & 0.27 & 0.27 \\
$\mathrm{~V}_{\text {Meso }}\left(\mathrm{cm}^{3} / \mathrm{g}\right)^{\mathrm{c}}$ & 0.05 & 0.23 & 0.27 \\
$\mathrm{~S}_{\mathrm{BET}}\left(\mathrm{m}^{2} / \mathrm{g}\right)^{\mathrm{c}}$ & 754 & 840 & 805 \\
$\mathrm{~S}_{\text {Ext }}\left(\mathrm{m}^{2} / \mathrm{g}\right)^{\mathrm{c}}$ & 60 & 267 & 261 \\
${\text { Crystallinity }(\%)^{\mathrm{d}}}$ & 100 & 70 & 70 \\
\hline
\end{tabular}

${ }^{\mathrm{a}}$ unit cell parameter; ${ }^{\mathrm{b}}$ determined by ${ }^{29} \mathrm{Si}$ MAS NMR; ${ }^{\mathrm{c}}$ determined by nitrogen sorption at $77 \mathrm{~K} ;{ }^{\mathrm{d}}$ relative to LZY-64

\section{RESULTS AND DISCUSSION}

\section{Adsorption of basic probe molecules monitored by IR Internal and external acidity of the FAU structure: Pyridine (Py)}

Figure1a shows the IR spectra of LZY-64 activated at $723 \mathrm{~K}$ before and after pyridine adsorption. After activation, three absorption bands are observed in the $v(\mathrm{OH})$ region:

$-3740 \mathrm{~cm}^{-1}$ : silanol groups

- $3640 \mathrm{~cm}^{-1}$ and $3545 \mathrm{~cm}^{-1}$ : bridging hydroxyl groups (Brønsted acid sites, BAS) respectively located in the supercages $\left(\mathrm{OH}_{\mathrm{HF}}\right)$ and sodalite cages $\left(\mathrm{OH}_{\mathrm{LF}}\right)$.

After pyridine adsorption and evacuation at $523 \mathrm{~K}$, the supercages BAS $\left(3640 \mathrm{~cm}^{-1}\right)$ disappear almost completely while those in the sodalite cages $\left(3545 \mathrm{~cm}^{-1}\right)$ are unaffected, Figure 1 . The number of BAS determined by this procedure is reported in Table 2 . As expected, the majority of acidic sites accessible to pyridine are located in the supercages $(1260 \mu \mathrm{mol} / \mathrm{g})$ and the proportion of acidic sites accessible to pyridine in sodalite cages is negligible. The difference in the number of acid sites estimated by IR and ${ }^{29} \mathrm{Si}$ NMR for LZY-64 is a direct consequence of the presence of residual sodium cations ( $c a .3 \%$ determined by ICP analysis). The ACI of pyridine in LZY-64 is 0.4 and implies that only $40 \%$ of the acidic sites, all located in in the supercages, are accessible to molecules with a kinetic diameter of about $0.55 \mathrm{~nm}$.

The same procedure is applied to CBV760, Figure 1b. In contrast to LZY-64, the acidic sites in the sodalite cages become accessible to pyridine as both $\mathrm{OH}_{\mathrm{HF}}$ and $\mathrm{OH}_{\mathrm{LF}}$ bands disappear after pyridine adsorption. While the number of Brønsted acid sites is much lower on CBV760, their accessibility to pyridine is higher (0.5), although the presence of extraframework aluminum could hinder access to some acid sites. The Brønsted acid site concentration expected from the ${ }^{29} \mathrm{Si} \mathrm{NMR}$ derived framework composition $(520 \mu \mathrm{mol} / \mathrm{g})$ is significantly higher than those detected $(320 \mu \mathrm{mol} / \mathrm{g})$ and accessible $(240 \mu \mathrm{mol} / \mathrm{g})$ by IR spectroscopy. $\left({ }^{65}\right)$ 

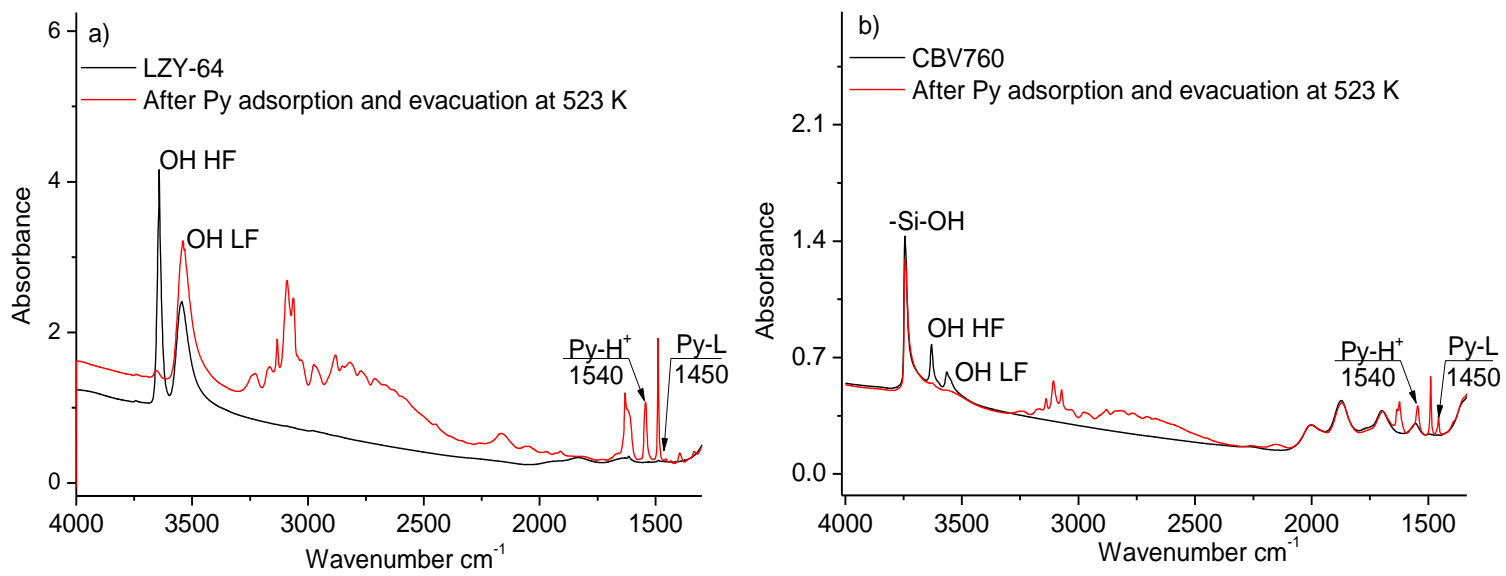

Figure 1. IR spectra before and after adsorption of pyridine and evacuation at $523 \mathrm{~K}$ under vacuum: $a$ ) LZY-64 and $b$ ) CBV760.

Table 2 : Acid site concentration in LZY-64 and CBV760.

\begin{tabular}{|c|c|c|c|c|c|c|c|c|c|}
\hline Sample & $\mathrm{OH}_{\mathrm{HF} \mu \mathrm{mol} / \mathrm{g}^{\mathrm{a}}}$ & $\mathrm{OH}_{\mathrm{LF} \mu \mathrm{mol} / \mathrm{g}^{\mathrm{a}}}$ & $\sum_{\mu \mathrm{mol} / \mathrm{g}} \mathrm{b}$ & $\sum_{\mu \mathrm{mol} / \mathrm{g}} \mathrm{c}$ & $\mathrm{Al}^{\mathrm{IV}}$ & $\underset{\mu \mathrm{mol} / \mathrm{g}}{\mathrm{Py}-\mathrm{H}^{+}}$ & $\underset{d}{P y}-\mathbf{L}$ & $\mu \mathrm{mol} / \mathrm{g}$ & $\mathbf{A C I}_{\mathbf{P y}}{ }^{e}$ \\
\hline LZY-64 & 1260 & 2090 & 3350 & 3570 & & 1390 & 45 & & 0.4 \\
\hline CBV760 & 140 & 180 & 320 & 520 & & 240 & 84 & & 0.5 \\
\hline
\end{tabular}

${ }^{\text {a }}$ determined using molar absorption coefficients of $\mathrm{OH}$ bands $\left({ }^{24}\right)$

${ }^{\mathrm{b}}$ sum of all bridging hydroxyls: $\mathrm{OH}_{\mathrm{HF}}+\mathrm{OH}_{\mathrm{LF}}$

${ }^{c}$ tetrahedral (framework) aluminum calculated from the $\mathrm{Si} / \mathrm{Al}$ ratios determined by ${ }^{29} \mathrm{Si} \mathrm{NMR}$

${ }^{\mathrm{d}} \mathrm{Py}-\mathrm{H}^{+}$: protonated pyridine (Brønsted sites), Py-L: coordinated pyridine (Lewis sites)

${ }^{\mathrm{e}}$ accessibity index of pyridine $=\mathrm{Py}-\mathrm{H}^{+} / \Sigma \mathrm{Al}^{\mathrm{IV}}$

\section{External acidity of the FAU structure: the case of 2,6 Di-tert-butylpyridine (DTBPy)}

This bulky molecule (kinetic diameter: $0.8 \mathrm{~nm}$ ) is already used to probe the external acidity of different zeolite types such as MOR, ZSM-5. $\left({ }^{31,66}\right)$ However, on LZY-64 and CBV760, the $\mathrm{OH}_{\mathrm{HF}}$ band (supercages) decreases upon DTBPy adsorption and evacuation at $523 \mathrm{~K}$, while the $\mathrm{OH}_{\mathrm{LF}}$ (sodalite cages) remains intact or slightly broadened, Figure 2. New bands appear at 3360, 1616 and $1530 \mathrm{~cm}^{-1}$, characteristic of protonated DTBPy. The IR spectra of LZY-64 after exposure to DTBPy for 0-64 minutes are shown in Figure 3a and the variation of the integrated intensity of the 3360 $\mathrm{cm}^{-1}$ band (DTBPyH+) with the amount of $\mathrm{OH}_{\mathrm{HF}}$ consumed (molar absorption of $6.76 \mu \mathrm{mol} \mathrm{cm}^{-1}$ ) in Figure 3b. An excellent linear correlation $\left(\mathrm{r}^{2}=0.99\right)$ with a zero intercept allows to calculate the molar absorption coefficient $\left({ }^{5.22}\right.$ $\mathrm{cm} . \mu \mathrm{mol}^{-1}$ ) of the $3360 \mathrm{~cm}^{-1}$ band of DTBPyH ${ }^{+}$assuming DTBPy adsorbs specifically on OHHF. The resulting number of acidic sites $(1013 \mu \mathrm{mol} / \mathrm{g})$ probed by 2,6 DTBPy is reported in Table 3.

While this demonstrates an expected lower accessibility of DTBPy than Py to both LZY-64 and CBV760 acid sites, DTBPy nevertheless interacts with internal acidity, including sodalite cages in CBV760. Therefore it cannot be considered a suitable probe for the external surface of FAU structures. 

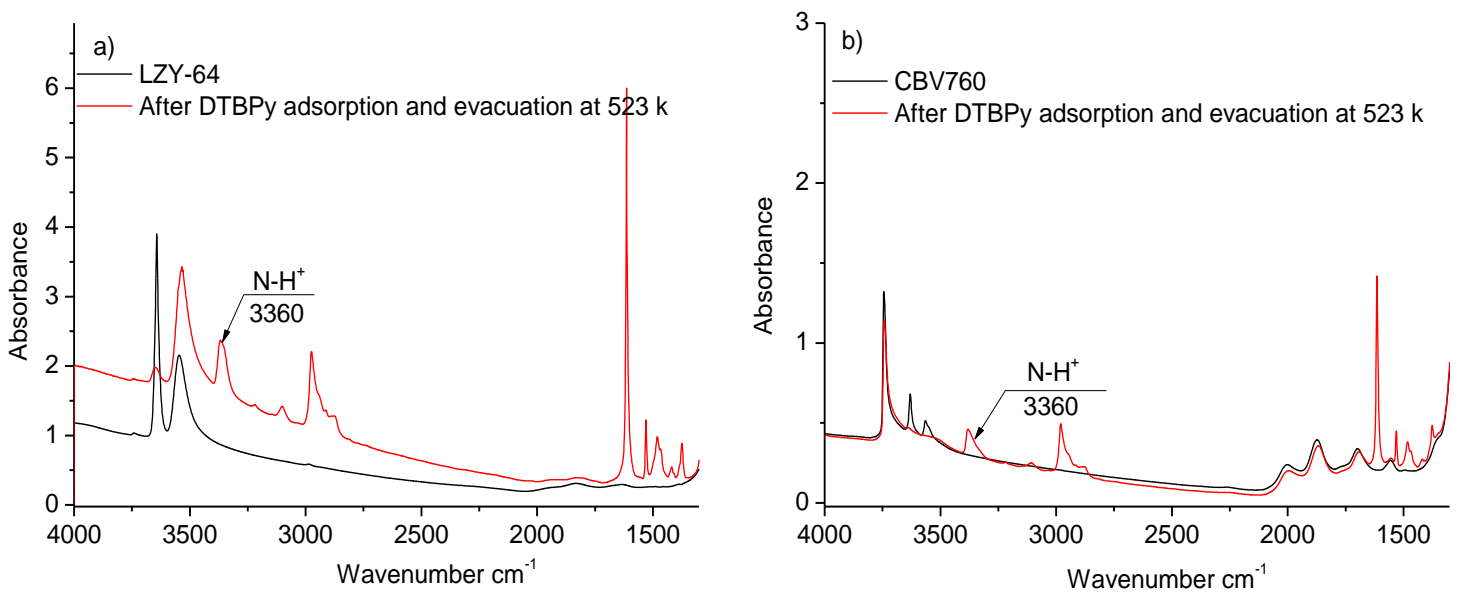

Figure 2. IR spectra before and after adsorption of 2,6 Di-tert-butylpyridine (DTBPy) and after evacuation at $523 \mathrm{~K}$ under vacuum: $a$ ) LZY-64 and $b$ ) CBV760.
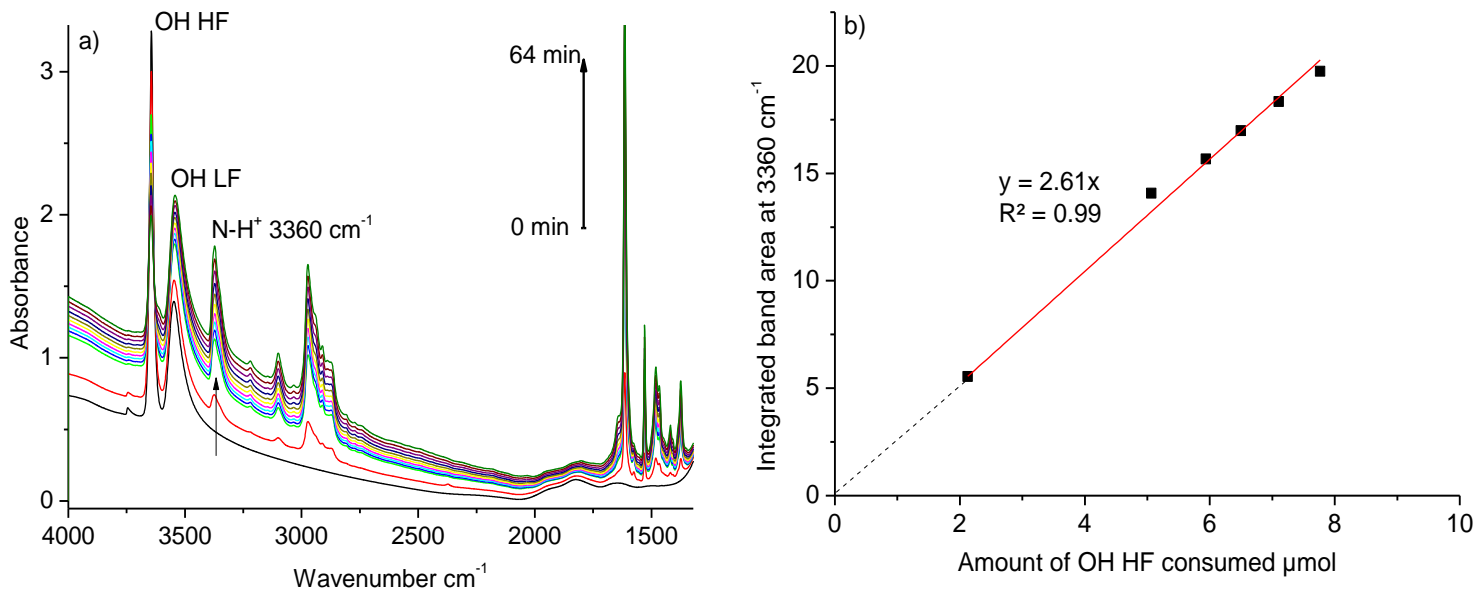

Figure 3. a) Time evolution of the IR spectra of LZY-64 in contact with 2,6 DTBPy, $b$ ) integrated band area at $3360 \mathrm{~cm}^{-1}$ as a function of the $\mathrm{OH}_{\mathrm{HF}}$ consumed.

Table 3. Acidic properties of LZY-64 and CBV760 probed by Py and DTBPy.

\begin{tabular}{|c|c|c|c|c|c|}
\hline Sample & $\underset{\mu \mathrm{mol} / \mathrm{g}}{\Sigma \mathbf{A l}^{\mathrm{IV}}}$ & $\underset{\mu \mathrm{Pol} / \mathrm{g}}{\mathbf{P}}$ & $\mathbf{A C I} \mathbf{I}_{\mathbf{p y}}{ }^{\mathrm{c}}$ & $\begin{array}{c}\text { DTBPy-H } \\
\mu \mathrm{mol} / \mathrm{g} \\
\mathrm{d}\end{array}$ & $\mathbf{A C I _ { \text { DTBP } }}{ }^{\mathrm{e}}$ \\
\hline LZY-64 & 3565 & 1391 & 0.4 & 1013 & 0.3 \\
\hline CBV760 & 520 & 240 & 0.5 & 197 & 0.4 \\
\hline
\end{tabular}

${ }^{a}$ concentration of framework aluminum determined by ${ }^{29} \mathrm{Si} \mathrm{NMR}$

${ }^{\mathrm{b}} \mathrm{Py}-\mathrm{H}^{+}$: concentration of Pyridine adsorbed on Brønsted acid sites after evacuation at $423 \mathrm{~K}$

${ }^{c}$ accessibity index of pyridine $=\mathrm{Py}-\mathrm{H}^{+} / \Sigma \mathrm{Al}^{\mathrm{IV}}$

${ }^{\mathrm{d}}$ DTBPy- $\mathrm{H}^{+}$: concentration of DTBPy adsorbed on Brønsted acid sites after evacuation at $423 \mathrm{~K}$

${ }^{\mathrm{e}}$ accessibity index of 2,6 DTBPy $=\mathrm{DTBPy}-\mathrm{H}^{+} / \Sigma \mathrm{Al}^{\mathrm{IV}}$ 


\section{External acidity of the FAU structure: a quest for the right molecule}

n-Tributylamine (TBA), 2,4 dimethylquinoline (DMQ), n-trihexylamine (THA) and 2,4,6 tri-tert-butylpyridine (TTBPy) are selected as their adsorption/diffusion in the microporosity at $298 \mathrm{~K}$ might become slow enough to discriminate between internal and external acidity during IR monitored uptake experiments. As discussed above, the amount of adsorbed probe molecules is determined by following the consumption of the $\mathrm{OH}$ bands (molar absorption coefficients from Ref. 24) assuming one probe molecule adsorbs per acid site. Figure 4 shows the disappearance of the $\mathrm{OH}_{\mathrm{HF}}\left(3640 \mathrm{~cm}^{-1}\right)$ band of LZY-64 as a function of $\sqrt{t}(\mathrm{t}=$ exposure time, in $\mathrm{s})$ at $298 \mathrm{~K}$ for these candidates. Except for TTBPy and THA, a monotonous uptake of the probe molecule is observed.

DTBPy, often used to probe the external acid sites of large pore zeolites (MOR, BEA...) zeolites, enters the microporosity of LZY-64, and reaches about $16 \%$ of the acid sites within 20 min. Both TBA and DMQ behave similarly, albeit slower. DMQ, for instance reaches $16 \%$ of the acidic sites, after 1 hour at $298 \mathrm{~K}$. THA on the other hand first adsorbs slowly, reaching a plateau after consuming about $2 \%$ of the acid sites, to finally reach $14 \%$ of the Bronsted sites after 2 hours. The plateau corresponds to the expected quantity of THA adsorbed on the external surface sites, in good agreement with earlier computed geometric external surface of zeolite Y. $\left({ }^{67}\right)$ In the case of this particular LZY-64, its geometric surface evaluated assuming spherical crystallites (500 nm diameter) and no Al zoning, as described elsewhere, $\left({ }^{58,71}\right)$ amounts to $10 \mathrm{~m}^{2} / \mathrm{g}$, i.e. the external acid sites contribute to about $1.3 \%$ of the total acidity, i.e. $45 \mu \mathrm{mol} / \mathrm{g}$ of zeolite.

In contrast to the above probes, liquid at room temperature, the TTBPy uptake is slow and progressive reaching a final plateau when about $2 \%$ of the acid sites are neutralized (inset in Figure 4) indicating that it never accesses the microporosity at $298 \mathrm{~K}$ and interacts only with the external Brønsted acidity. Again, assuming that one molecule is adsorbed per acid site, the external acid sites of zeolite is estimated to $50 \mu \mathrm{mol} / \mathrm{g}$. However, at a higher temperature, 373 K, TTBPy penetrates zeolite Y microporosity.

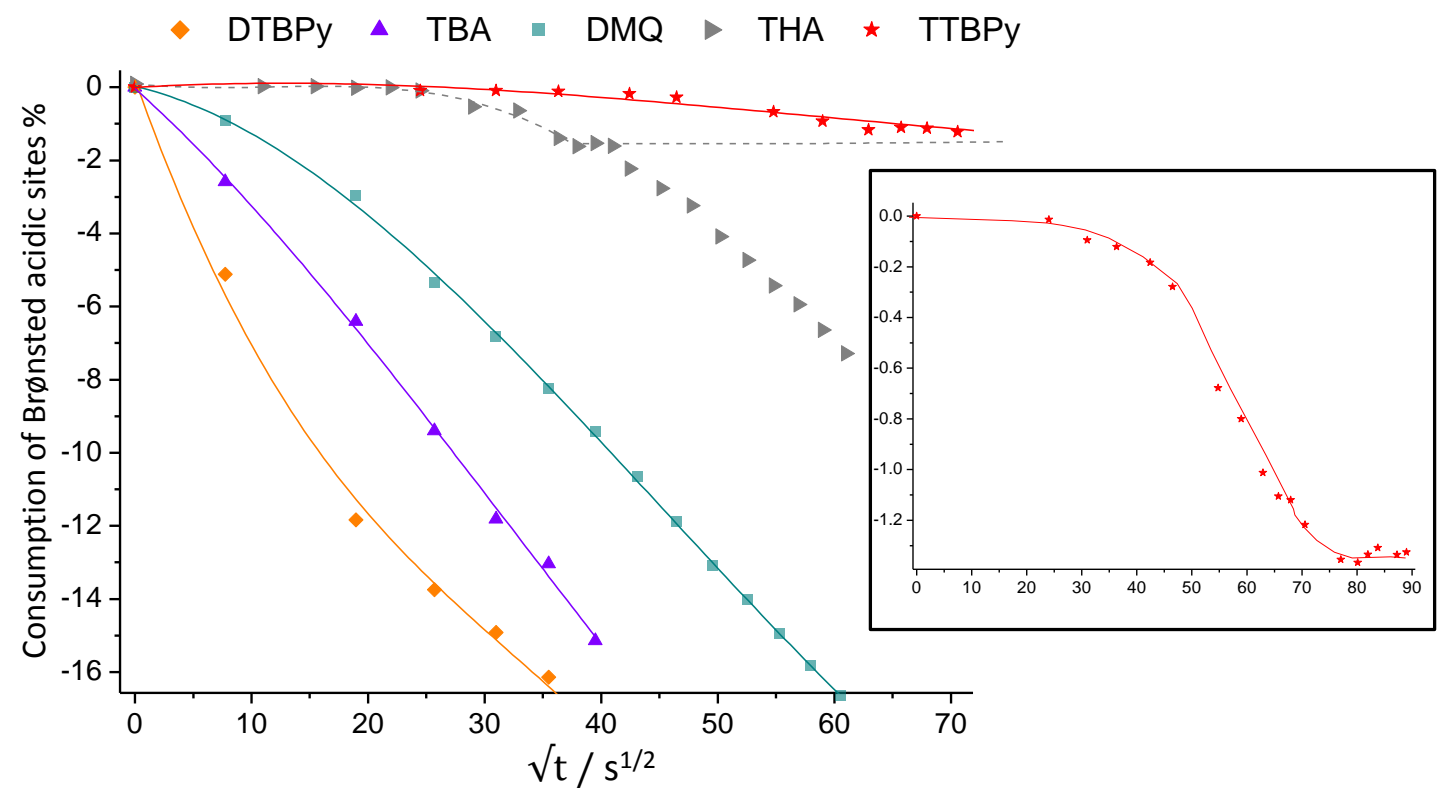

Figure 4. Consumption of the LZY-64 Brønsted acidity as a function of the square root of exposure time,$\sqrt{t}$, at $298 \mathrm{~K}$ for various basic probe molecules (inset: zoom on TTBPy).

In order to better quantify the TTBPy adsorbed on the BAS of the USY zeolites, with higher Si/Al, the molar extinction coefficient of its protonated form, $\mathrm{TTBPy}^{+}$, is determined, vide infra. Figure 5 shows the spectra of TTBPy vapor (a), 1 wt \% TTBPy dispersed in $\mathrm{KBr}$ (b) and a difference spectrum i.e. the pristine LZY-64 spectra substracted form TTBPY adsorbed on LZY-64 (c). The latter displays new bands at 3365, 3350, 1612 and $1373 \mathrm{~cm}^{-1}$. The 3365 and $3350 \mathrm{~cm}^{-1}$ are assigned to $v(\mathrm{~N}-\mathrm{H}+)$ vibrations of protonated TTBPy. $\left({ }^{68}\right)$ The molar absorption coefficient of the $v(\mathrm{~N}-\mathrm{H}+)$ band at $3365 \mathrm{~cm}^{-1}$ is determined as for 2,6 DTBPy, vide supra. 


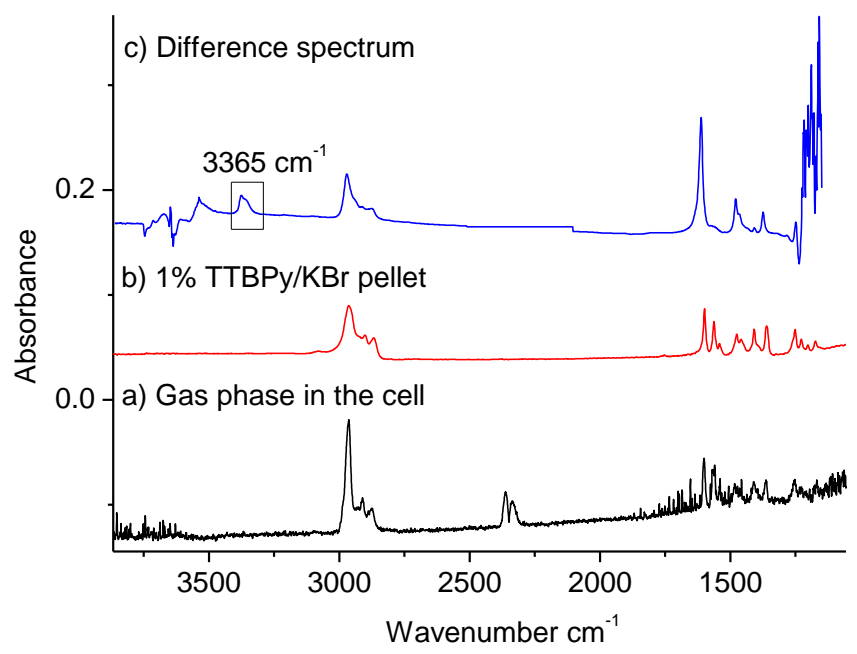

Figure 5. IR spectra of a) gas phase (TTBPy) in the cell (x 40), b) $1 \% \mathrm{TTBPy} / \mathrm{KBr}$ pellet, c) difference spectrum between TTBPY adsorbed on LZY-64 and the pristine LZY-64 (298 K).

The TTBPyH ${ }^{+}\left(3370-3350 \mathrm{~cm}^{-1}\right)$ integrated area correlates $\left(\mathrm{r}^{2}=0.99\right)$ well with the intensity decrease of the $\mathrm{OH}_{\mathrm{HF}}$, (Figure $6 \mathrm{~b}$ ). The derived molar absorption coefficient, $\varepsilon$, is $5.74 \mathrm{~cm}^{\prime} \mu \mathrm{mol}^{-1}$. TTBPy is also adsorbed on CBV720 and CBV760 (298 K followed by evacuation under vacuum at RT for $15 \mathrm{~min}$ ) and compared with LZY-64 (Figure 7). This confirms that on LZY-64, as with Py and DTBPy, only the $\mathrm{OH}_{\mathrm{HF}}$ band decreases while the $\mathrm{OH}_{\mathrm{LF}}$ broadens. Table 4 summarizes the TTBPy results on the three zeolites and the associated accessibilities (ACI).

On that basis, we conclude that THA and TTBPy are suitable molecules to probe the external surface of FAU; TTBPy should be preferred as it does not enter the zeolite microporosity, even after upon prolonged exposure.
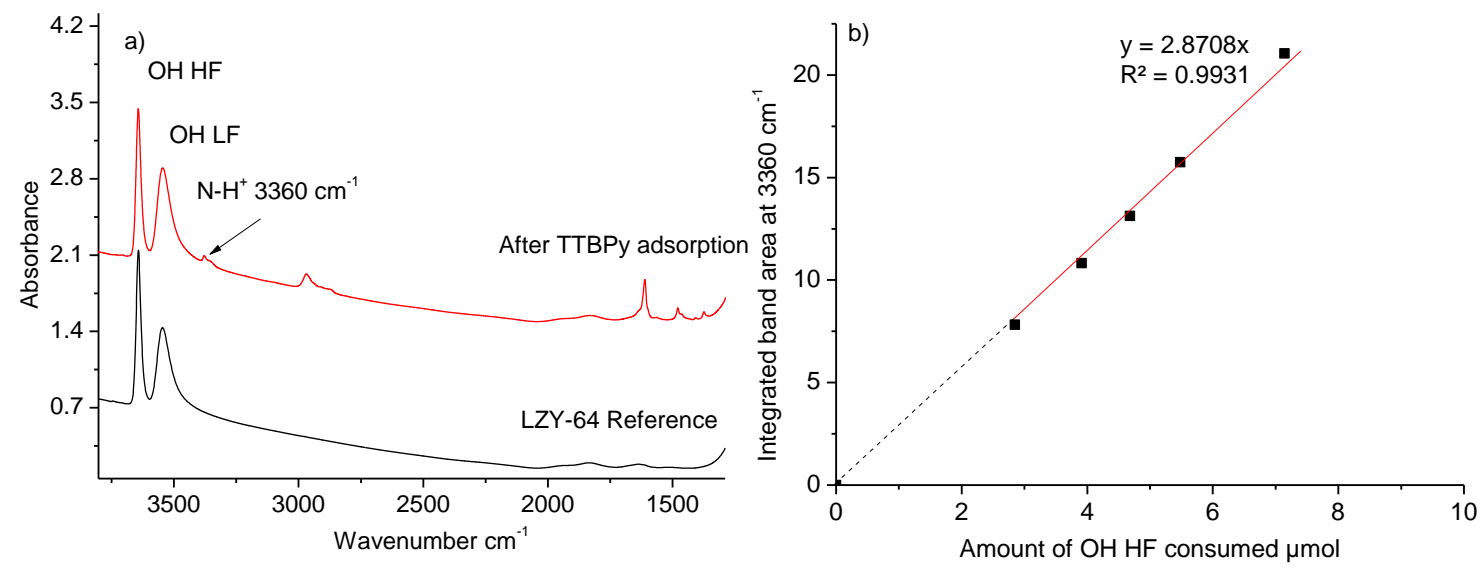

Figure 6. a) IR spectra of LZY-64 before and after 120 min contact with TTBPY vapor at $298 \mathrm{~K}, b$ ) integrated intensity of the $3360 \mathrm{~cm}^{-1}$ band as a function of $\mathrm{OH}_{\mathrm{HF}}$ consumed. 


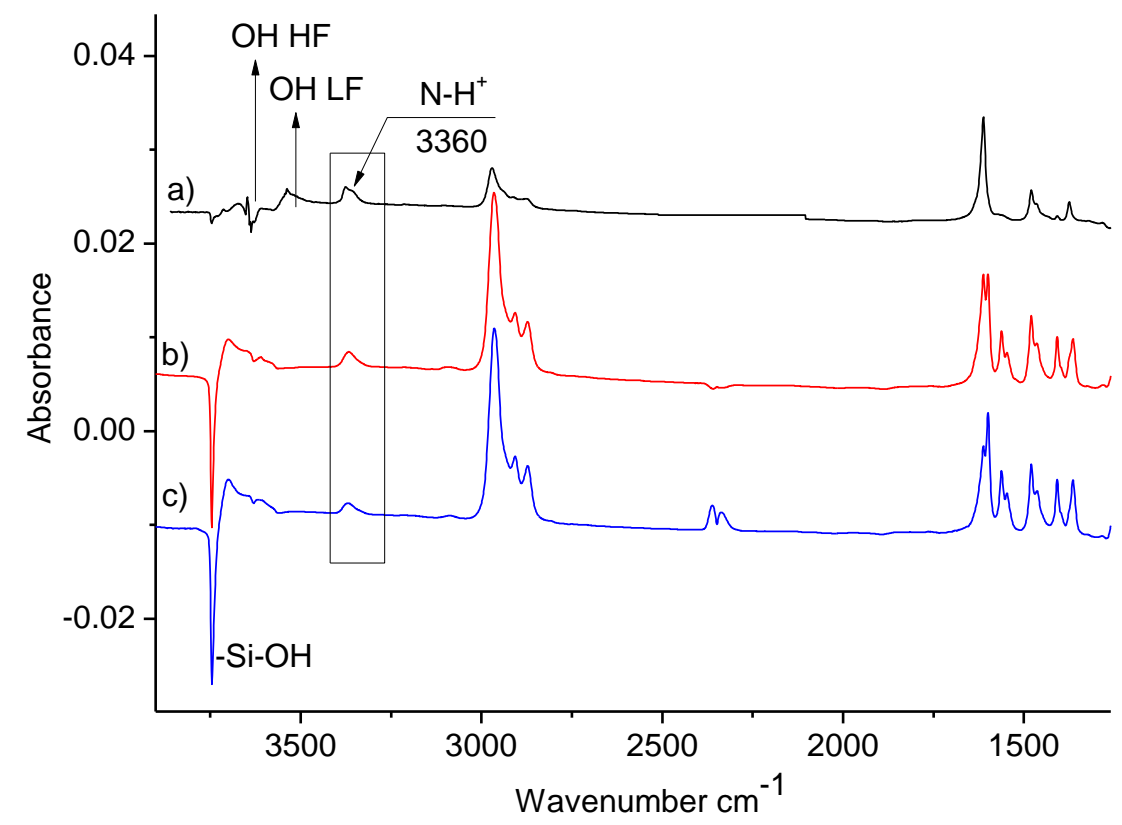

Figure 7. IR spectra of TTBPy adsorbed at $298 \mathrm{~K}$ and evacuated under vacuum at room temperature for 15 min on $a$ ) LZY64, b) CBV720, c) CBV760.

Table 4. External acidity of LZY-64, CBV720 and CBV760 zeolites probed by TTBPy.

\begin{tabular}{lll}
\hline Zeolite & $\begin{array}{l}\text { TTBPy-H } \\
{ }^{+} \mathbf{a}^{+}\end{array}$ & $\begin{array}{l}\text { ACI } \\
{ }^{\text {TTBPY }}{ }^{b}\end{array}$ \\
\hline LZY-64 & 60 & 0.02 \\
\hline CBV720 & 24 & 0.04 \\
\hline CBV760 & 20 & 0.04 \\
\hline
\end{tabular}

${ }^{\text {a }}$ TTBPy- $\mathrm{H}^{+}$: Tri-tert-butylpyridine molecules adsorbed on Brønsted sites after evacuation

${ }^{\mathrm{b}}$ accessibility index of TTBPy $=$ TTBPy- $\mathrm{H}^{+} / \Sigma \mathrm{Al}^{\mathrm{IV}}$

\section{Adsorption of basic probe molecules monitored by ${ }^{31} \mathrm{P}$ NMR}

Internal and external acidity of the FAU structure: Trimethylphosphine oxide (TMPO)

LZY-64 and CBV760 zeolites are loaded with an excess of TMPO to guarantee a complete titration of all acid sites ( $4 \mathrm{mmol}$ of TMPO/g zeolite, dissolved in $1 \mathrm{ml}$ of $\mathrm{CH}_{2} \mathrm{Cl}_{2}$ ). When all acid sites are titrated, a peak due to physisorbed (solid) TMPO emerges between 39-43 ppm and serves as an internal standard. 


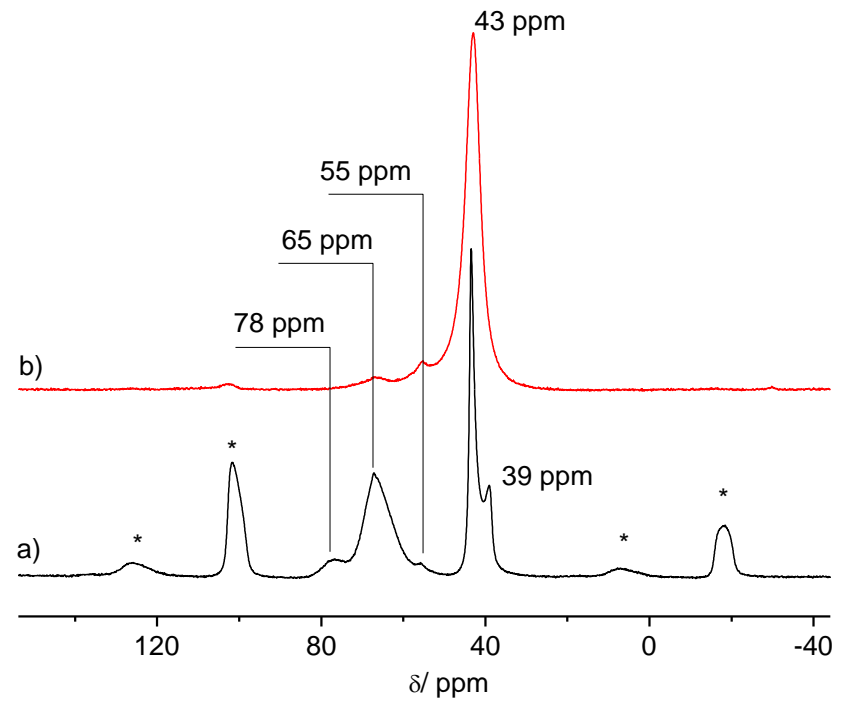

Figure 8. ${ }^{31}$ P MAS NMR spectra of TMPO adsorbed on $a$ ) LZY-64, b) CBV760 (*: spinning side bands).

It is well established that TMPO accesses the microporosity of zeolite Y. $\left({ }^{46}\right)$ The ${ }^{31} \mathrm{P}$ NMR MAS spectrum of pure TMPO, Figure S.3, displays two signals at 39 and 43 ppm. The first is assigned to crystalline TMPO while the second is due to interaction between $\mathrm{P}=\mathrm{O}$ and traces of water. $\left({ }^{69,33,69,70}\right)$ Figure 8 shows the ${ }^{31} \mathrm{P}$ NMR spectra of TMPO adsorbed on LZY-64 and CBV760. On LZY-64, three signals in the 55-80 ppm range are assigned to Brønsted acid sites. ${ }^{45,48,49,50}$ ) Obenaus et al. assigned the $55 \mathrm{ppm}$ resonance to TMPO interacting with Brønsted acid sites in the sodalite cages, while those at 65 and $78 \mathrm{ppm}$ to the Brønsted acid sites located in the supercages. $\left({ }^{71}\right)$ The ${ }^{31} \mathrm{P}$ NMR spectrum of CBV760 shows similar features to LZY-64, except the $78 \mathrm{ppm}$ resonance. The number of acid sites measured by TMPO in LZY-64 is therefore $3046 \mu \mathrm{mol} / \mathrm{g}$ showing that, as expected, TMPO interacts with almost all acid sites, including those located in sodalite cages ( $\mathrm{ACI}=0.85)$.

\section{External acidity of the FAU structure: Triphenylphosphine oxide (TPhPO)}

TPhPO is a bulky molecule (kinetic diameter of of $1.1 \mathrm{~nm}$ ) previously used by Ryoo et al. to measure the external acidity of highly mesoporous MFI structures. $\left({ }^{33,72}\right)$ As it should have a highly restricted access to the zeolite $\mathrm{Y}$ microporosity, it is a potential candidate to interact specifically with its external acidic sites. The ${ }^{31} \mathrm{P}$ NMR spectrum of pure TPhPO, displays two resonances, $24 \mathrm{ppm}$ and $28 \mathrm{ppm}$, assigned respectively to crystalline TPhPO and hydrated $\mathrm{TPhPO}$ due, as for TMPO, to interactions between $\mathrm{P}=\mathrm{O}$ and traces of water as, Figure 9. Upon adsorption on LZY-64 and CBV760, its ${ }^{31} \mathrm{P}$ NMR spectra display three resonances around 24, 28 and $30 \mathrm{ppm}$. On $\gamma$-alumina, the $28 \mathrm{ppm}$ resonance of adsorbed TPhPO is attributed to its interaction with Lewis acid sites (Figure S.4). However, on a zeolite, $\mathrm{TPhPO}$ is too sterically hindered to interact with Lewis acidic sites. By analogy with TMPO, vide supra, we assign the $28 \mathrm{ppm}$ resonance to physisorbed TPhPO and the $30 \mathrm{ppm}$ one to TPhPO adsorbed on Brønsted acidic sites. The amount of Bronsted sites accessible to TPhPO on LZY-64 $(53 \mu \mathrm{mol} / \mathrm{g})$ and CBV760 $(19 \mu \mathrm{mol} / \mathrm{g})$ are consistent with those obtained by IR with TTBPy, a molecule of similar size (Table 5). 


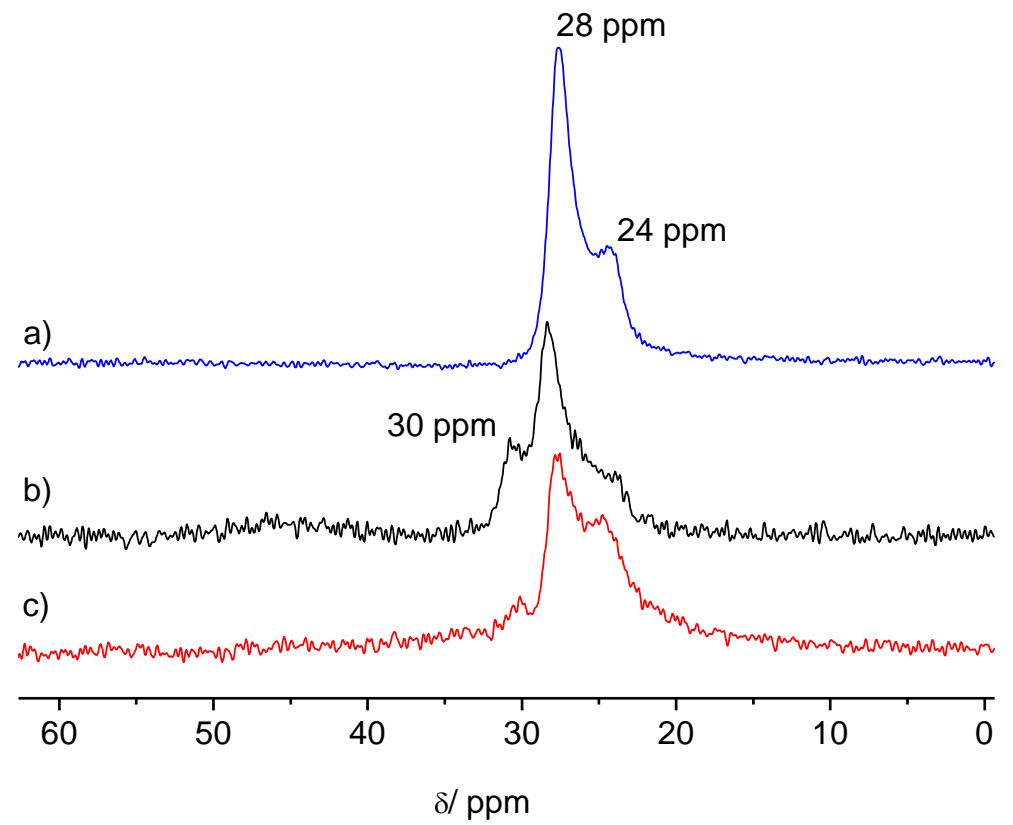

Figure 9. ${ }^{31} \mathrm{P}$ MAS NMR spectra of TPhPO $a$ ) pure, $b$ ) adsorbed on LZY-64, $c$ ) adsorbed on CBV760

Table 5. External acidity of LZY-64, CBV720 and CBV760 zeolites probed by TTBPy and TPhPO bulky basic molecules.

\begin{tabular}{|c|c|c|}
\hline \multirow[t]{2}{*}{ Zeolite } & \multicolumn{2}{|c|}{ Surface Brønsted acid site density $\mu \mathrm{mol} / \mathrm{g}$} \\
\hline & TTBPy $\left(\right.$ IR) ${ }^{\mathrm{a}}$ & TPhPO (NMR) ${ }^{b}$ \\
\hline LZY-64 & 60 & 53 \\
\hline CBV720 & 24 & 25 \\
\hline CBV760 & 20 & 19 \\
\hline
\end{tabular}

${ }^{\text {a }}$ TTBPy: Tri-tert-butylpyridine molecules adsorbed on Brønsted sites

${ }^{\mathrm{b}}$ TPhPO: Tri-phenylphosphine oxide molecules adsorbed on Brønsted sites

\section{CONCLUSIONS}

For the first time, the Brønsted acidity of the external surface of the FAU type structure, the archetype large pore zeolite, is measured. It is quantified by titration with probe molecules monitored by readily available and proven spectroscopic techniques, IR and NMR. Some bulky but flexible molecules (Tri-hexylamine, $1.3 \times 1.4 \mathrm{~nm}$ ) access both its external and internal acidity even when adsorption takes place at room temperature while others, less flexible (Tritert-butyl pyridine and Tri-phenylphosphine oxide, both $1.1 \times 1.1$ ) probe only the external acidity. The room temperature adsorption of tri-tert-butylpyridine monitored by IR spectroscopy indicates that $2 \mathrm{w} \%$ (Y) and $4 \mathrm{w} \%$ (USY) of the total acid sites, i.e. $60 \mu \mathrm{mol} / \mathrm{g}$ and $20 \mu \mathrm{mol} / \mathrm{g}$ respectively are located on the external surface. ${ }^{31} \mathrm{P}$ NMR spectroscopy of adsorbed triphenylphosphine oxide (TPhPO) leads to very similar conclusions.

This advance opens the door to a more quantitative and deeper understanding of the catalytic performances of zeolites, in particular, the nanosized and hierarchical ones where the external surface plays an even more important role. $\left({ }^{43}\right)$ It will participate to a better description of structure-reactivity using the Thiele modulus approach and bring more insights in the structural and chemical changes occurring during the shaping of zeolites in technical bodies as this operation affects mainly the external surface, as reported recently. $\left({ }^{16}\right)$

More insight is however required to establish better structure-activity correlations and design superior zeolitic catalysts. For instance, advanced NMR techniques $\left({ }^{69}\right)$ should bring more knowledge on the exact nature of the external acid sites while recent methodologies where calorimetric data are acquired together with the IR spectra of adsorbed probe molecules could provide information on the strength and the environment (confinement) of these acid 
sites. $\left({ }^{73}\right)$ Last but not least, advances in computational modelling will become ever more helpful to better understand the role of the external surface of zeolites, the compulsory ports of entry to their micropores. $\left({ }^{19}\right)$

\section{ASSOCIATED CONTENTS}

Supporting Information is available free of charge via the Internet at http://pubs.acs.org : Physical properties and molecular dimensions of the basic probe molecules, schemes of the infrared and NMR cells and ${ }^{31} \mathrm{P}$ NMR spectra of the phosphorous based probe molecules.

\section{AUTHOR INFORMATION}

Corresponding Author

* Email: jean-pierre.gilson@ensicaen.fr.

*Email: suheil.abdo@honeywell.com.

\section{Funding sources}

Honeywell UOP

\section{ACNOWLEDGMENT}

Honeywell UOP for funding and permission to publish

\section{SYNOPSIS TOC}

External vs Internal zeolite $Y$ acidity

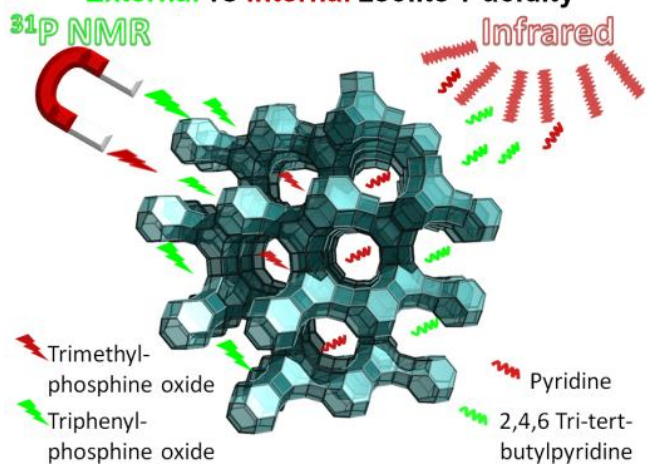

\section{REFERENCES}

(1) Rigutto, M. S.; Van. Veen, R.; Huve, L. Introduction to Zeolite Science and Practice, Vol. 168 ed. Čejka, J. ;Van Bekkum, H.; Corma, A.; Schüth, F. Elsevier, Amsterdam 2007, 855-914.

(2) Kulprathipanja, S.; Zeolites in Industrial Separation and Catalysis, Wiley-VCH, Weinheim, Germany 2010.

(3) Marcilly, C.; Acido-Basic Catalysis - Application to Refining and Petrochemistry, Editions Technip, Paris 2005.

(4) Sheldon, R. A.; Van Bekkum, H. Fine Chemicals Through Heterogeneous Catalysis, Wiley-VCH, Weinheim 2000.

(5) Ennaert, T.; Van Aelst, J.; Dijkmans, J.; De Clercq, R.; Schutyser, W.; Dusselier, M.; Verboekend, D.; Sels, B. F. Potential and challenges of zeolite chemistry in the catalytic conversion of biomass. Chem. Soc. Rev. 2016, 45, 584-611.

(6) Vermeiren, W.; Gilson, J.-P. Impact of Zeolites on the Petroleum and Petrochemical Industry. Top Catal. 2009, 52, 11311161.

(7) Van den Berg, J.; Gascon, J.; Kapteijn, F. in Zeolites and Catalysis - Synthesis, Reactions and Applications, ed. Cejka, J.; Corma, A.; Zones, S. I. Wiley-VCH, Weinheim 2010, 361-387.

(8) Chen, N. Y.; Degnan, T. F.; Morris, C. Molecular Transport and Reaction in Zeolites, Wiley-VCH, Weinheim 1994.

(9) Schwieger, W.; Gonche Machoke, A.; Reiprich, B.; Weissenberger, T.; Selvam, T.; Hartmann, M. Zeolites in Catalysis: Properties and Applications Čejka, J.; Morris R. E. eds. the Royal Society of Chemistry 2017, 103-145.

(10) Cohen, D.; Merchuk, J.; Zeiri, Y.; Sadot, O. Catalytic effectiveness of porous particles: A continuum analytic model including internal and external surfaces. Chem. Eng. Sci. 2017, 166, 101-106.

(11) Thommes, M.; Kaneko, K.; Neimark, A. V.; Olivier, J. P.; Rodriguez-Reinoso, F.; Rouquerol, J.; Sing, K. S. W.; Physisorption of gases with special reference to the evaluation of surface area and pore size distribution. Pure Appl. Chem. 2015, 87, 1051-1069. 
(12) Von Ballmoos, R.; Meier W. M. Zoned aluminium distribution in synthetic zeolite ZSM-5. Nature 1981, 289, 782-783.

(13) Derouane, E. G.; Gilson, J.-P.; Gabelica, Z.; Mousty-Desbuquoit, C.; Verbist, J. Concerning the aluminum distribution gradient in ZSM-5 zeolites. J. Catal. 1981, 71, 447-448.

(14) Van Bokhoven, J.; Danilina, D. Aluminum in Zeolites: Where is it and what is its structure? in Zeolites and Catalysis, Čejka, J.; Corma, A.; Zones, S. eds. Wiley-VCH, Weinheim 2010, 283-298.

(15) Kraushaar-Czarnetzki, B. Shaping of Solid Catalysts, in Synthesis of Solid Catalysts, De Jong, K. P. ed. Wiley-VCH, Weinheim 2009, 173-199.

(16) Lakiss, L.; Gilson, J. -P.; Valtchev, V.; Mintova, S.; Vicente, A.; Vimont, A.; Bedard, R.; Abdo, S.; Bricker, J. Shaping Zeolite Y Catalysts by Extrusion: Characterization and Catalytic Consequences of Zeolite-Binder Interactions. submitted to Microporous Mesoporous Mater.

(17) Derouane, E. G. Shape selectivity in catalysis by zeolites: The nest effect . J. Catal. 1986, 100, $541-544$.

(18) Wang, S.; Iglesia, E. Catalytic diversity conferred by confinement of protons within porous aluminosilicates in Prins condensation reactions. J. Catal. 2017, 352, 415-435.

(19) Rey, J.; Raybaud, P.; Chizallet, C. Ab Initio simulation of the acid sites at the external surface of zeolite Beta. ChemCatChem 2017, 9, 2176-2185.

(20) Gorte, R. J. What do we know about the acidity of solid acids? Catal. Lett. 1999, 62, 1-13.

(21) Corma, A.; Fornes, V.; Melo, F. V.; Herrero, J. Comparison of the information given by ammonia t.p.d. and pyridine adsorption-desorption on the acidity of dealuminated HY and LaHY zeolite cracking catalysts. Zeolites 1987, 7, 559-563.

(22) Tonetto, G.; Atias, J.; De Lasa, H. FCC catalysts with different zeolite crystallite sizes: acidity, structural properties and reactivity. Appl. Catal. A 2004, 270, 9-25.

(23) Oliviero, L.; Vimont, A.; Lavalley, J. C.; Romero Sarria, F.; Gaillard, M.; Maugé, F. 2,6-Dimethylpyridine as a probe of the strength of Brønsted acid sites: study on zeolites. Application to alumina. Phys. Chem. Chem. Phys. 2005, 7, 1861-1869.

(24) Thibault-Starzyk, F.; Gil, B.; Aiello, S.; Chevreau, T.; Gilson, J.-P. In situ thermogravimetry in an infrared spectrometer: an answer to quantitative spectroscopy of adsorbed species on heterogeneous catalysts. Microporous Mesoporous Mater. 2004, 67, 107-112.

(25) Zecchina, A.; Spoto, G.; Bordiga, S. Probing the acid sites in confined spaces of microporous materials by vibrational spectroscopy. Phys. Chem. Chem. Phys. 2005, 7, 1627-1642.

(26) Bordiga, S.; Lamberti, C.; Bonino, F.; Travert, A.; Thibault-Starzyk, F. Probing zeolites by vibrational spectroscopies. Chem. Soc. Rev. 2015, 44, 7262-7341.

(27) Gilson, J.-P.; Fernandez, C.; Thibault-Starzyk, F. New insights on zeolite chemistry by advanced IR and NMR characterization tools. J. Mol. Catal. A: Chemical 2009, 305, 54-59.

(28) Lercher, J. A.; Grundling, C.; Eder-Mirth, G. Infrared studies of the surface acidity of oxides and zeolites using adsorbed probe molecules. Catal. Today 1966, 353-376.

(29) Vimont, A.; Thibault-Starzyk, F.; Daturi, M. Analysing and understanding the active site by IR spectroscopy. Chem. Soc. Rev. 2010, 39, 4928-4950.

(30) Sarria, F. R.; Blasin-Aube, V.; Saussey, J.; Marie, O.; Daturi, M. Trimethylamine as a Probe Molecule To Differentiate Acid Sites in Y-FAU Zeolite: FTIR Study. J. Phys. Chem. B 2006, 110, 13130-13137.

(31) Corma, A.; Fornes, V.; Forni, L.; Marquez, F.; Martinez-Triguero, J.; Moscottiy, D. 2, 6-Di-tert-butyl-pyridine as a probe molecule to measure external acidity of zeolites. J. Catal. 1998, 179, 451-458.

(32) Hunger, M. Brønsted Acid Sites in Zeolites Characterized by Multinuclear Solid-State NMR Spectroscopy. Catal. Rev. Sci. Eng. 1997, 39, 345-393

(33) Zheng, A.; Liu, S. B.; Deng, F. ${ }^{31}$ P NMR Chemical Shifts of Phosphorus Probes as Reliable and Practical Acidity Scales for Solid and Liquid Catalysts. Chem. Rev. 2017, 117, 12475-12531.

(34) Choudhary, V. R.; Akolekar, D. B. Comparison of the acidity/site energy distribution in catalytically important zeolites. $J$. Catal. 1989, 119, 525-530.

(35) Thibault-Starzyk, F.; Abelló, S.; Bonilla, A.; Thomas, K.; Fernandez, C.; Gilson, J.-P.; Ramírez, J. P. Quantification of enhanced acid site accessibility in hierarchical zeolites-the accessibility index. J. Catal. 2009, 264, 11-14.

(36) Maache, M.; Janin, A.; Lavalley, J. C.; Benazzi, E. FT infrared study of Brønsted acidity of H-mordenites: Heterogeneity and effect of dealumination. Zeolites 1995, 15, 507-516.

(37) Nesterenko, N. S.; Thibault-Starzyk, F.; Montouilliout, V.; Yushchenko, V. V.; Fernandez, C.; Gilson, J.-P.; Fajula, F.; Ivanova, I. I. The use of the consecutive adsorption of pyridine bases and carbon monoxide in the IR spectroscopic study of the accessibility of acid sites in microporous/mesoporous materials. Kinetics and Catal. 2006, 7(1), 40-48.

(38) Freitas, C.; Barrow, N. S.; Zholobenko, V. Accessibility and Location of Acid Sites in Zeolites as Probed by Fourier Transform Infrared Spectroscopy and Magic Angle Spinning Nuclear Magnetic Resonance. Johnson Matthey Technol. Rev. 2018, 62(3), 279-290

(39) Armaroli, T.; Bevilacqua, M.; Trombetta, M.; Milella, F.; Alejandre, A. G.; Ramirez, J.; Notari, B.; Willey, R. J.; Busca, G. A study of the external and internal sites of MFI-type zeolitic materials through the FT-IR investigation of the adsorption of nitriles. Appl. Catal. A: Gen. 2001, 216 (1-2), 59-71.

(40) Bevilacqua, M.; Meloni, D.; Sini, F.; Monaci, R.; Montanari, T.; Busca, G. A study of the nature, strength, and accessibility of acid sites of H-MCM-22 zeolite. J. Phys. Chem. C 2008, 112, 9023-9033.

(41) Bevilacqua, M.; Busca, G. A study of the localization and accessibilty of Brønsted and Lewis acid sites of H-Mordenite through the FT-IR spectroscopy of adsorbed branched nitriles. Catal. Commun. 2002, 3, (11), 497-502.

(42) Montanari, T.; Bevilacqua, M.; Busca, G. Use of nitriles as probe molecules for the accessibility of the active sites and the detection of complex interactions in zeolites through IR spectroscopy. Appl. Catal. A: Gen. 2006, 307, (1), 21-29.

(43) Tzoulaki, D.; Jentys, A.; Pérez-Ramírez, J.; Egeblad, K.; Lercher, J. A. On the location, strength and accessibility of Brønsted acid sites in hierarchical ZSM-5 particles. Catal. Today 2012, 198, 1,3-11.

(44) Gallas, J.-P.; Goupil, J. M.; Vimont, A.; Lavalley, J. C.; Gil, B.; Gilson, J. -P.; Miserque, O. Quantification of Water and Silanol Species on Various Silicas by Coupling IR Spectroscopy and in-Situ Thermogravimetry. Langmuir 2009, 25, 5825-5834. 
(45) Yu, S.; Tian, H. Acidity characterization of rare-earth-exchanged Y zeolite using ${ }^{31} \mathrm{P}$ MAS NMR. Chinese Journal of Catal. 2014, 35, 1318-1328.

(46) Sutovich, K. J.; Peters, A. W.; Rakiewicz, E. F.; Wormsbecher, R. F.; Mattingly, S. M.; Mueller, K. T. Simultaneous Quantification of Brønsted and Lewis-Acid Sites in a USY Zeolite. J. Catal. 1999, 183, 155-158.

(47) Guan, J.; Li, X.; Yang, G.; Zhang, W.; Liu, X.; Han, X.; Bao, X. Interactions of phosphorous molecules with the acid sites of H-Beta zeolite: Insights from solid-state NMR techniques and theoretical calculations. J. Mol. Catal. A: Chemical 2009, 310, $113-$ 120.

(48) Rakiewicz, E. F.; Peters, A. W.; Wormsbecher, R. F. Characterization of Acid Sites in Zeolitic and Other Inorganic Systems Using Solid-State ${ }^{31}$ P NMR of the Probe Molecule Trimethylphosphine Oxide. J. Phys. Chem. B 1998, 102, 2890-2896.

(49) Karra, M. D.; Sutovich, K. J.; Mueller K. T. NMR Characterization of Bronsted Acid Sites in Faujasitic Zeolites with Use of Perdeuterated Trimethylphosphine Oxide. J. Am. Chem. Soc. 2002, 124(6), 902-903.

(50) Wiper, P. V.; Amelse, J.; Mafra, L. Multinuclear solid-state NMR characterization of the Brønsted/Lewis acid properties in the BP HAMS-1B (H-[B]-ZSM-5) borosilicate molecular sieve using adsorbed TMPO and TBPO probe molecules. J. Catal. 2014, $316,240-250$

(51) Baltusis, L.; Frye, J. S.; Maciel, G. E. Phosphine oxides as NMR probes for adsorption sites on surfaces. J. Am. Chem. Soc. 1986, 108, 7119-7120.

(52) Sang, H.; Chu, H. Y.; Lunsford, J. H. An NMR study of acid sites on chlorided alumina catalysts using trimethylphosphine as a probe. Catal. Lett. 1994, 26, 235-246.

(53) Lunsford, J. H.; Rothwell, W. P.; Shen, W. Acid sites in zeolite Y: a solid-state NMR and infrared study using trimethylphosphine as a probe molecule. J. Am. Chem. Soc. 1985, 107, 1540-1547.

(54) Gilson, J.-P.; Derouane, E. G. On the external and intracrystalline surface catalytic activity of pentasil zeolites. J. Catal. 1984, 88, 538-541.

(55) Kunkeler, P. J.; Downing, R. S.; Van Bekkum, H. The use of Bulky Molecules as Probes for Investigating the Contributions of the External and Internal Pore-wall Activities of Zeolite Catalysts. Stud. Surf. Sci. Catal. 2001, 137, 987-1002.

(56) Weitkamp, J.; Ernst, S.; Puppe L. Shape-Selective Catalysis in Zeolites. Weitkamp J.; Puppe L. (eds.), Catalysis and Zeolites, Springer-Verlag Berlin Heidelberg 1999, 327-376.

(57) Degnan, T. F. The implications of the fundamentals of shape selectivity for the development of catalysts for the petroleum and petrochemical industries. J. Catal. 2003, 216, 32-46.

(58) Chen, C. S. H.; Schramm, S. E. Type and catalytic activity of surface acid sites of medium and large pore zeolites Their deactivation with bulky organophosphorus compounds. Microporous Materials 1996, 7, 125-132.

(59) Chen, N. Y. Personal Perspective of the Development of Para Selective ZSM-5 Catalysts. Ind. Eng. Chem. Res. 2001, 40, 4157-4161.

(60) Kaduk, J. A.; Faber, J. Crystal structure of zeolite Y as a function of ion exchange. J. Rigaku 1995, 12(2), 14-34.

(61) Qin, Z.; Cychosz, K. A.; Melinte, G.; El Siblani, H.; Gilson, J.-P.; Thommes, M.; Fernandez, C.; Mintova, S.; Ersen, O.; Valtchev, V. Opening the Cages of Faujasite-Type Zeolite. J. Am. Chem. Soc. 2017, 139, 17273-17276.

(62) Mintova, S.; Gilson, J.-P.; Valtchev, V. Advances in nanosized zeolites. Nanoscale 2013, 5, 6693-6703.

(63) Awala, H.; Gilson, J.-P.; Retoux, R.; Boullay, P.; Goupil, J. M.; Valtchev, V.; Mintova, S. Template-free nanosized Faujasite-type zeolites. Nature Mat. 2015, 14, 447-451.

(64) Van Koningsveld, H.; Jansen, J. C. Single crystal structure analysis of zeolite H-ZSM-5 loaded with naphthalene. Microporous Mater. 1996, 6, 159-167.

(65) Almutairi, S. M. T.; Mezari, B.; Filonenko, G. A.; Magusin, P. C. M. M.; Rigutto, M. S.; Pidko, E. A.; Hensen, E. J. M. Influence of Extraframework Aluminum on the Brønsted Acidity and Catalytic Reactivity of Faujasite Zeolite. ChemCatChem 2013, $5,452-466$.

(66) Gora-Marek, K.; Tarach, K.; Choi, M. 2,6-Di-tert-butylpyridine Sorption Approach to Quantify the External Acidity in Hierarchical Zeolites. J. Phys Chem C 2014, 118, 12266-12274.

(67) Farcasiu, M.; Degnan, T. The role of external surface activity in the effectiveness of zeolites. Ind. Eng. Chem. Res. 1988, 27, 45-47.

(68) Lin-Vien, D.; Colthup, N. B.; Fateley, W. G.; Grasselli, J. G. The handbook of Infrared and Raman characteristic frequencies of organic molecules. Academic press 1991, 163-168.

(69) Zheng, A. M.; Zhang, H. L.; Lu, X.; Liu, B. S.; Deng, F. 31P Chemical Shift of Adsorbed Trialkylphosphine Oxides for Acidity Characterization of Solid Acids Catalysts. J. Phys. Chem. B 2008, 112, 4496-4505.

(70) Begimova, G.; Tupikina, E. Y.; Yu, V. K.; Denisov, G. S.; Bodensteiner, M.; Shenderovich, I. G. Effect of Hydrogen Bonding to Water on the 31P Chemical Shift Tensor of Phenyl- and Trialkylphosphine Oxides and $\alpha$-Amino Phosphonates. J. Phys. Chem. C 2016, 120, 8717-8729.

(71) Obenaus, U.; Dyballa, M.; Lang, S.; Scheibe, M.; Hunger, M. Generation and Properties of Brønsted Acid Sites in Bifunctional Rh-, Ir-, Pd-, and Pt-Containing Zeolites Y Investigated by Solid-State NMR Spectroscopy. J. Phys. Chem. C 2015, $119,15254-15262$.

(72) Kyungsu, N.; Changbum, J.; Jeongnam, K.; Kanghee, C.; Jinhwan, J.; Yongbeom, S.; Messinger, J. R.; Chmelka, F. B.; Ryong, R. Directing Zeolite Structures into Hierarchically Nanoporous Architectures. Science 2011, 333, 328-332.

(73) Stošić, D.; Bennici, S.; Sirotin, S.; Stelmachowski, P.; Couturier, J. L.; Dubois, J. L.; Travert, A.; Auroux, A. Examination of acid-base properties of solid catalysts for gas phase dehydration of glycerol: FTIR and adsorption microcalorimetry studies. Catal. Today 2014, 226, 167-175. 